\title{
PEMBUATAN SEDIAAN MASKER TEPUNG BERAS ORGANIK DAN KAYU MANIS (Cinnamomum burmannii Nees ex BI) UNTUK MENGOBATI KULIT PADA WAJAH BERJERAWAT
}

\author{
Rudi $^{1}$, Farah Sulistyaningtyas ${ }^{2}$, Dewi Ratnasari ${ }^{3}$ \\ 1,2,3 Sekolah Tinggi Ilmu Kesehatan Holistik Purwakarta
}

\begin{abstract}
ABSTRAK
Latar Belakang : Tanaman yang memiliki khasiat obat dan digunakan sebagai obat dalam penyembuhan maupun pencegahan penyakit adalah yang berfungsi mengobati penyakit tertentu atau tidak mengandung zat aktif tertentu tapi mengandung efek resultan atau sinergi dari berbagai zat yang berfungsi mengobati. Obat herbal dapat menyembuhkan penyakit dengan efek samping yang minim karena dibuat dari bahan-bahan yang alami, tidak seperti obat sintetis yang dapat memberikan efek samping baik secara langsung maupun setelah waktu yang lama.
\end{abstract}

Tujuan:Penelitian ini bertujuan membuat sediaan masker dari campuran tepung beras organik dan kayu manis untuk mengobati kulit pada wajah berjerawat.Metode: Metode yang digunakan yaitu deskriptif kualitatif. Dalam penelitian ini dilakukan percobaan dengan menggunakan 3 sampel, sampel pertama tepung beras organik $10 \mathrm{gr}$, bubuk kayu manis $0,75 \mathrm{gr}$, dan $10 \mathrm{~mL}$ air. Sampel kedua tepung beras organik 10 gr, bubuk kayu manis 0,5 gr, dan $10 \mathrm{~mL}$ air. Sampel ketiga tepung beras organik 10 gr, bubuk kayu manis $0,25 \mathrm{gr}$, dan 10 $\mathrm{mL}$ air. Hasil: Hasil uji organoleptik terhadap campuran tepung beras organik 10 gr, bubuk kayu manis $0,25 \mathrm{gr}$, dan $10 \mathrm{~mL}$ air yang dilakukan selama 3 minggu menunjukkan tidak adanya perubahan warna, bau, dan rasa.

Simpulan: Bubuk kayu manis dan tepung beras organik dapat dibuat menjadi sedian masker serbuk untuk kulit berjerawat dan dapat bertahan selama 3 minggu.

Kata kunci : kayu manis, tepung beras organik, jerawat, masker.

Korespondensi

Dewi Ratnasari

Program Studi D3 Farmasi STIKes Holistik Purwakarta

J1. Veteran No.272 Ciseureuh Purwakarta

Email : dratnasari20@gmail.com

Phone : 0857-5919-6278 


\title{
PREPARATION OF A MASK ORGANIC RICE FLOUR AND \\ CINNAMON (Cinnamomum burmannii Nees ex BI) TO TREAT ACNE PRONE SKIN ON THE FACE
}

\begin{abstract}
Backgroud : Plants have medicinal properties and used as a medicine in the treatment or prevention of disease. Herbs can cure the disease with minimal side effects because it made from natural ingredients, unlike synthetic drugs which can give side effects either directly or after a long time.

Objective :To know the composition of the mask preparation of organic rice flour and cinnamon powder (Cinnamomum burmannii Nees ex Bl).

Method : The method used in this research is qualitative descriptive journals gathering in advance of studies on the efficacy of cinnamon powder and organic rice flour for acne prone skin in dosage forms mask.

This study attempted 3 samples, the first sample of $10 \mathrm{gr}$ organic rice flour, powdered cinnamon $0,75 \mathrm{gr}, 10 \mathrm{ml}$ water. The second sample $10 \mathrm{gr}$ organic rice flour, cinnamon powder $0,5 \mathrm{gr}, 10 \mathrm{ml}$ water. The third sample $10 \mathrm{gr}$ organic rice flour, powdered cinnamon $0,25 \mathrm{gr}, 10 \mathrm{ml}$ water. results obtained in this study is 10 gr organic rice flour, powdered cinnamon $0,25 \mathrm{gr}, 10 \mathrm{ml}$ water. organoleptic testing in this study carried out for 3 weeks with the result that the change in color, smell, taste.

Results: The Research obtained in this study is 10 gr organic rice flour, powdered cinnamon $0,25 \mathrm{gr}, 10 \mathrm{ml}$ water. Organoleptic test in this study was conducted over three weeks and the results showed no changes in color, taste and smell.

Conclusion: It can be concluded organic rice flour and cinnamon powder preparations can be made into powder mask for acne prone skin and can hold for three weeks.
\end{abstract}

Keywords: cinnamon, rice flour, skin breakouts, masks. 
Tanaman yang memiliki khasiat obat dan digunakan sebagai obat dalam penyembuhan maupun pencegahan penyakit adalah yang berfungsi mengobati penyakit tertentu atau tidak mengandung zat aktif tertentu tapi mengandung efek resultan atau sinergi dari berbagai zat yang berfungsi mengobati. Obat herbal dapat menyembuhkan penyakit dengan efek samping yang minim karena dibuat dari bahanbahan yang alami, tidak seperti obat sintetis yang dapat memberikan efek samping baik secara langsung maupun setelah waktu yang lama.

Pada dasarnya, pengobatan dengan obat herbal dilakukan melalui pendekatan yang bersifat holistik, yaitu tubuh manusia dipandang memiliki suatu sistem harmoni yang selalu seimbang sehingga apabila ada salah satu bagian tubuh bermasalah, akan timbul pula masalah pada bagian tubuh yang lain. Obat herbal di sini bekerja dengan cara memberi energi pada organ tubuh dan kelenjar tertentu serta menyeimbangkan kondisi tubuh sehingga membantu mengembalikan keharmonisan dan keseimbangan tubuh secara keseluruhan. Dalam aplikasinya, pengobatan dengan obat herbal diarahkan untuk menjaga dan mempertahankan sistem imun tubuh untuk melawan patogen (bibit penyakit) dari luar.

Salah satu herbal yang diteliti memiliki aktivitas antibakteri adalah kayu manis (Cinnamomum burmanni Neesex Bl.). Berdasarkan hasil riset yang dilakukan oleh para ahli, disebutkan bahwa herbal oil kayu manis maupun ekstrak etanol (50\%) kayu manis cinnamomum zeylanicum memiliki aktivitas antibakteri terhadap 10 jenis bakteri ${ }^{1}$. Penelitian lainnya menyebutkan bahwa (E)cinnamaldehyde (minyak atsiri) dan proanthocyanidins (folipenol) merupakan kandungan yang terdapat dalam herbal oil kulit batang kayu manis cinnamomum burmanii blume yang memberikan efek antibakteri ${ }^{2}$ sedangkan herbal oil daun kayu manis cinnamomum osmophloem mengandung cinnamaldehyde yang memiliki aktivitas antibakteri ${ }^{3}$. Kulit batang dan daun cinnamomum burmannii mengandung minyak atsiri, saponin dan flavonoida. Disamping itu kulit batang juga mengandung tannin, daunnya juga 
mengandung alkaloida dan polifenol ${ }^{4}$.

Sediaan bahan baku dari kayu manis digunakan sebagai tambahan pengobatan tradisional kulit wajah manusia dikelompokkan menjadi lima jenis yaitu kulit normal, kombinasi, berminyak, kering, dan sensitif. Kulit normal ditandai dengan kulit tidak berminyak dan tidak kering, sehingga kelihatan segar dan bagus, pori-pori hampir tidak kelihatan. Pengeluaran kotoran dan penyerapan zat-zat yang berguna melalui kulit serta peredaran darah yang berjalan dengan baik, akan jarang mendapat gangguan jerawat maupun timbulnya cacat-cacat pada kulit muka dan tonusnya baik.

Masalah pada kulit dapat ditimbulkan oleh bakteri, jamur atau virus yang dapat menyebabkan terjadinya infeksi kulit ${ }^{5}$. Dari lima jenis kulit wajah, masalah kulit paling sering terjadi pada kulit wajah berminyak yang disebabkan oleh bakteri. Masalah pada kulit yang disebabkan oleh bakteri memicu terjadinya infeksi kulit, ekzema (kulit kering atau gatal), dermatitis (radang kulit), tinea, folikulitis, impetigo dan jerawat. Jerawat muncul disebabkan oleh empat faktor yaitu kelenjar minyak yang terlalu aktif, penyumbatan pori-pori, aktifitas bakteri kulit dan peradangan. Kelenjar minyak yang terlalu aktif berkaitan dengan kulit dan pori-pori. ${ }^{6}$ Produksi minyak berlebih dari kelenjar minyak membuat pori-pori menjadi tersumbat karena adanya penumpukan minyak, yang menyebabkan adanya aktivitas bakteri didalam pori-pori yang tersumbat.

Aktivitas bakteri mengakibatkan terjadinya infeksi, sehingga kulit mengalami peradangan. Peradangan pada kulit berjerawat terjadi untuk melawan zat asing berupa bakteri atau senyawa lainnya. Berdasarkan penyebab timbulnya masalah-masalah pada kulit, jerawat merupakan masalah kulit wajah yang mudah muncul sehingga perlu dilakukan perawatan untuk menyembuhkan jerawat. Tepung beras dapat digunakan sebagai bahan dasar masker kulit wajah, karena mengandung amilosa, amilopektin, hydralized amylum/dekstrin, gamma oryzanol dan asam kojik yang dapat mencerahkan kulit sebagai hasil dari 
fermentasi amylum selama perendaman. ${ }^{7}$ Sediaan masker gel peel off mengandung ekstrak kulit batang kayu manis memiliki organoleptis, homogenitas, $\mathrm{pH}$, dan kemampuan mengering yang baik dan memenuhi persyaratan persyaratan yang ada. ${ }^{8}$ Untuk kemudahan dan kenyamanan penggunaan kayu manis perlu diformulasikan dalam bentuk sediaan topikal, salah satunya adalah masker serbuk. Masker serbuk merupakan bentuk masker yang paling awal dan populer. Masker serbuk terbuat dari bahan-bahan yang dihaluskan dan diambil serbuknya.

Berdasarkan latar belakang diatas, penulis tertarik untuk melakukan penelitian dengan judul “pembuatan sedian masker tepung beras organik dan kayu manis (Cinnamomum burmannii Nees ex Bl ) untuk mengobati kulit pada wajah berjerawat" dikarenakan, sebagian masyarakat belum mengetahui bahwa kulit batang kayu manis bisa digunakan sebagai masker mengobati kulit untuk wajah jerawat.

\section{METODE PENELITIAN}

Jenis penelitian ini adalah penelitian eksperimen. Penelitian eksperimen adalah suatu cara untuk mencari hubungan sebab akibat (hubungan kasual) antara dua faktor yang sengaja ditimbulkan oleh peneliti dengan mengeliminasi atau mengurangi atau menyisihkan faktorfaktor lain yang mengganggu. ${ }^{9}$

Kulit batang kayu manis (Cinnamomum burmanni Neesex Bl.) diperoleh dari pasar senin kabupaten Purwakarta, Provinsi Jawa Barat. Beras diperoleh di bioshop holistic Purwakarta Provinsi Jawa Barat. Setelah mendapatkan kedua bahan tersebut, beras dibersihkan dengan cara dicuci dan kulit batang kayu manis hanya di bersihkan pakai kain saja supaya tidak ada kotoran yang menempel. Setelah kedua bahan tersebut dibersihkan beras digiling menggunakan mesin giling tepung, dan kulit batang kayu manis (Cinnamomum burmanni Neesex Bl.) diblender. Kemudian kedua bahan tersebut di oven pada suhu $78^{\circ} \mathrm{C}$ selama 30 menit, dan ditiriskan selama 15 menit lalu diayak menggunakan pengayak nomor. 60 
supaya bahan terlihat halus, lalu kedua bahan dimasukan dalam plastik terpisah dan ditutup rapat agar tidak lembab.

\section{HASIL PENELITIAN}

Dari hasil percobaan tiga sampel, menunjukan bahwa sampel pertama sangat kental, sampel kedua masih terlihat kental, dan sampel ketiga kekentalannya cukup. Maka sediaan yang dipakai menggunakan sampel yang ketiga, yaitu campuran tepung beras 10 gr, bubuk kayu manis $0,25 \mathrm{gr}$, dan $10 \mathrm{~mL}$ air.

\section{Sampel pertama}

Tepung beras 10 gr, Bubuk kayu manis $0,75 \mathrm{gr}$, dan $10 \mathrm{~mL}$ air, menghasilkan sediaan yang sangat kental. Hal ini menunjukkan jumlah air yang ditambahkan kurang banyak.

2. Sampel kedua

Tepung beras 10 gr, Bubuk kayu manis $0,5 \mathrm{gr}$, dan $10 \mathrm{~mL}$ air, menghasilkan sediaan yang masih sangat kental walaupun tidak sekental sediaan yang pertama.
3. Sampel ketiga Tepung beras 10 gr, Bubuk kayu manis $0,25 \mathrm{gr}$, dan $10 \mathrm{~mL}$ air, menghasilkan sediaan dengan kekentalannya cukup untuk memenuhi kriteria masker.

\section{PEMBAHASAAN PENELITIAN}

Tanaman kayu manis (Cinnamomum burmannii Nees ex B1.) didapat di daerah pasar Senin Purwakarta, Provinsi Jawa Barat. Beras diperoleh di bioshop holistic Purwakarta. Pemilihan tanaman kayu manis diambil batangnya dengan pemilihan batang kayu manis yang sudah kering dengan warna kulit coklat. Sedangkan untuk pemilihan beras dipakai beras organik holistic yang tidak menggunakan bahan pemutih sehingga tidak mengandung bahan-bahan kimia didalamnya. Proses pemupukan yang dilakukan pada padi beras organik yaitu dengan menggunakan pupuk organik seperti kotoran hewan dan daun yang dikeringkan.

Tanaman kayu manis (CinnamomumburmanniiNeesex Bl.) memiliki kandungan sinamaldehid yang berkhasiat sebagai antibakteri, sedangkan beras memiliki 
kandungan amylum yang berkhasiat untuk mencerahkan kulit sehingga kedua bahan tersebut dibuat dalam sediaan masker serbuk untuk merawat kulit berjerawat. Hal ini dikarenakan kedua tumbuhan tersebut bisa membunuh bakteri sekaligus mencerahkan kulit. ${ }^{10}$

Pada penelitian ini dibuat sediaan masker menggunakan bahan batang kayu manis (Cinnamomum burmanni Neesex Bl.) dan tepung beras organik yang diperoleh di Purwakarta, Jawa Barat. Kedua bahan tersebut kemudian digiling tepung hasil penggilingan dimasukan kedalam plastik secara terpisah dan disimpan ditempat yang tidak berlembab.

Tepung hasil penggilingan kemudian dibawa ke laboratorium PT. Bio Medicine untuk dioven. Tepung beras organik dan bubuk kayu manis masing-masing dimasukan ke dalam wadah terpisah, untuk penimbangan kedua bahan tersebut menggunakan timbangan digital. Tepung beras ditimbang sebanyak 50 gr dan bubuk kayu manis sebanyak $25 \mathrm{gr}$.

Kedua tepung tersebut dioven pada suhu $78^{\circ} \mathrm{C}$. Waktu pengovenan diusahakan tidak boleh terlalu lama agar minyak atsiri yang terkandung didalam kayu manis tidak menguap dan hilang zat khasiatnya. Setelah pengovenan tepung beras organik dan kayu manis didiamkan selama 15 menit agar serbuk yang telah dioven menjadi dingin dan benar-benar kering tidak lembab.

Tepung beras organik dan bubuk kayu manis setelah di oven di haluskan dengan menggunakan pengayak nomor 60 , supaya tepung beras organik dan bubuk kayu manis terlihat lebih halus dan tidak ada partikel asing, setelah itu kemudian disimpan didalam wadah secara terpisah.

Langkah selanjutnya, tepung beras organik dan bubuk kayu manis dibawa ke laboratorium Stikes Holistik untuk pembuatan sampel masker. Sampel dibuat menjadi tiga dengan takaran seperti yang terlihat pada Tabel 1, di bawah ini: 
Tabel 1. Komposisi sampel

\begin{tabular}{cccc}
\hline Sampel & $\begin{array}{c}\text { Tepung Beras organik } \\
(\text { Gram) }\end{array}$ & $\begin{array}{c}\text { Tepung kayu manis } \\
\text { (Gram) }\end{array}$ & $\begin{array}{c}\text { Air } \\
(\mathbf{m L})\end{array}$ \\
\hline $\mathbf{1}$ & 10 & 0,75 & 10 \\
$\mathbf{2}$ & 10 & 0,5 & 10 \\
$\mathbf{3}$ & 10 & 0,25 & 10 \\
\hline
\end{tabular}

Dari hasil tiga sampel tersebut setelah dicampur dengan air menunjukan bahwa :

1. Sampel pertama menunjukan bahwa sediaan masker terlihat sangat kental, warna masker terlihat coklat pekat, bau masker khas kayu manis.

2. Sampel kedua menunjukan bahwa sediaan masker masih terlihat kental, warna masker coklat sedikit pekat, dan bau khas kayu manis.

3. Sampel ketiga menunjukan bahwa sediaan masker terlihat kekentalannya cukup, warna masker tidak terlalu pekat, dan bau khas kayu manis.

Dari ketiga sampel tersebut yang membentuk hasil optimal menunjukan pada sampel ketiga yaitu tepung beras organik $10 \mathrm{gr}$, bubuk kayu manis 0,25 gr, dengan warna tidak terlalu pekat dan bau khas kayu manis.
Setelah didapat komposisi yang ideal, kemudian dilakukan uji organoleptis meliputi pengamatan bentuk, warna, bau, rasa, dan berjamur atau tidaknya selama tiga minggu dan pengecekan dilalukan setiap hari.

Berdasarkan penelitian yang dilakukan selama 21 hari yang ditempatkan pada suhu kamar yaitu suhu $28^{\circ} \mathrm{c}$ dan suhu kulkas $15^{\circ} \mathrm{c}$. Hasil pengamatan yang dilakukan selama 21 hari menunjukan tidak terjadinya perubahan warna dari hari ke 1 sampai dengan hari ke 21 yaitu berwarna putih tulang, sedangkan dari pengamatan aroma, beraroma khas kayu manis dan tidak berjamur serta rasa yang keset sedikit mint sehingga menunjukan bahwa kondisi sediaan tersebut benar-benar stabil di dua tempat dan suhu yang berbeda. Karena sebelum diteliti selama tiga minggu tepung beras organik dan bubuk kayu manis dikeringkan pada suhu $78^{\circ} \mathrm{C}$, supaya sediaan tersebut bisa bertahan atau bisa dipakai 
dalam jangka waktu cukup lama, serta sediaan tersebut tidak berjamur dan tetap beraroma khas kayu manis. Kayu manis diharapkan efektif sebagai antioksidan serta antibakteri sehingga dapat diaplikasikan sebagai antioksidan dan pengawet alami ${ }^{11 .}$ Penelitian ini hanya hingga ke tahap pembuatan sediaan dan adapun pengujian dilakukan yaitu pengujian organoleptik hanya dilihat dari bau, rasa dan warna. Penelitian ini tidak sampai diujicobakan pada kulit wajah manusia, sehingga khasiat sediaan untuk pemakaian pada wajah belum diketahui.

\section{SIMPULAN}

Sediaan dengan komposisi serbuk beras 10 gr dan bubuk kayu manis 0,25 gr dan $10 \mathrm{~mL}$ air menunjukkan kekentalan yang memenuhi kriteria masker dan uji organoleptis yang diamati selama 3 minggu tidak ada perubahan warna, bau, dan rasa maka sediaan tersebut tetap stabil.

\section{DAFTAR PUSTAKA}

1. Gupta C, Garg AP, Uniyal RC, dkk. Comparative Analysis of the Antimicrobial Activity of Cinnamon Oil and Cinamon Extract on Somefood-borne Microbes. African Journal of Microbiology Research. 2008; 2(9): 247-251.

2. Shan B, Cai YZ, Brooks JD, et al. Antibacterial Properties and Major Bioactive Components of Cinnamon Stick (Cinnamomum burmannii): Activity against Foodborne Pathogenic Bacteria. Journal of Agricultural and Food Chemistry. 2007; 55: 54845490.

3. Chang ST, Chen PF, Chang SC. Antibacterial Activity of leaf Essential Oils and Their Constituents from Cinnamomu osmophloeum. Journal of Ethnopharmacology. 2001; 77: 123-127.

4. Angelica, N. Aktivitas antibakteri ekstrak etanol daun dan kulit batang kayu manis (cinnamomumburmannii (nees $\&$ th.nees) terhadap escherichia coli dan staphylococcus aureus. Diunduh dari

URL: 
http://repository.ubaya.ac.id.htm

1 Diakses pada 09 Agustus 2016.

5. Santoso, B. Buku Pintar Perawatan Kulit Terlengkap. Jogjakarta: Buku Biru; 2012.

6. Fauzi, Ridwan dan Nurmalina, R. Merawat Kulit dan Wajah. Jakarta: Kompas Gramedia; 2012.

7. Sulistianingrum, F. Pengaruh Perbedaan Persentase Tepung Biji Buah Pinang Terhadap Kualitas Sediaan Masker Kulit Wajah Berbahan Dasar Tepung Beras Sebagai Kosmetika Tradisional. Diunduh dari URL: http://ejournal.unesa.ac.id.html Diakses pada 04 Mei 2016.

8. Mutiara,R. Uji aktivitas antioksidan ekstrak kulit batang kayu manis (cinnamomumburmanniNees ex B1.) dan formulasinya dalam bentuk sediaan masker gel peel off. Diunduh dari URL: http://repository.unisba.ac.id.htm 1 Diakses pada 04 Juni 2016.
9. Suharsimi, A. Prosedur Penelitian Suatu Pendekatan Praktik. Jakarta: Bumi Aksara; 2010.

10. Apriyani. Aktivitas antibakteri minyak batang kayu manis (Cinnamomum burmanni Nees ex Bl) terhadap bakteri propionibacterium acnes. Diunduh dari URL: http://karyailmiah.unisba.ac.id/in dex.php/farmasi/article/downloa d/1935/pdf Diakses pada 01 Agustus 2016.

11. Andriyanto, A. Pengaruh Penambahan Ekstrak Kayu Manis Terhadap Kualitas Sensoris, Aktivitas Antioksidan dan Aktivitas Antibakteri Pada Telur Asin Selama Penyimpanan Dengan Metode Penggaraman Basah. Diunduh dari URL: http://www.ilmupangan.fp.uns.a c.id Diakses pada 09 Agustus 2016. 